\title{
PŘEHLEDOVÉ STATI
}

\section{Cesta k neo-modernímu typu smrti}

\author{
LENKA BERANOVÁ*
}

\section{Journey to Neo-modern Type of Death}

\begin{abstract}
This text aims to trace the thematisation of death and dying in Sociology, which in the 1990' evolves into constituion of independent sociological sub-discipline: "sociology of dying and death". The main intention then is to go beyond the commonly held belief that the death is still a taboo.

The arcticle consists of six thematic parts: first part summarizes the occurence of problems of dying and death in sociology, reflecting recent developments not only in social sciences, but also in the society as such. Theretofore the death is interpreted by religion but has been medicalized so that nowadays medicine represents the determinative paradigm of death (second part). This development is in accordance with the most important framework in the intensely individualized society centered around the notion of "self", closely connected with the concept of body and embodiment (third part). Fourth part summarizes the evolution of new sub-discip-line and the fifth part is concerned with the revival concept of death in the work of British sociologist Tony Walter. On the basis of the comparison of traditional, modern and neo-modern model of death we comment on social phenomena associated with other relevant conceptions. Sixth part is focused on the problems of "good death".
\end{abstract}

Keywords: dying, medicalization, Tony Walter, revivalism, neo-moderm death, good death, self

Texty o smrti a umírání zpravidla začínají prohlášením, že je smrt v moderní společnosti tabuizovaná. V zahraniční literatuře se v poslední době množí práce, které naopak poukazují na opačné tendence. Jinými slovy tedy skutečnost, že tabuizace smrti je do jisté míry věcí minulosti a že problematika umírání se znovu vrací do sféry zájmu, jak v odborné tak i ve veřejné rovině [Howarth 2007; Walter 2001].

V následují stati nejdřive naznačíme, jak byla a je smrt tematizována v sociologii. Poté tuto problematiku ukážeme v kontextu práce britského sociologa Tonyho Waltera, který do sociálních věd přinesl nový pojem - „revivalismus“1. Cílem textu je pokusit se odhalit jistou koherenci vývoje tematizování této otázky v sociologickém myšlení s Walterovými modely tradiční, moderní a neo-moderní smrti a v neposlední řadě přispět k problematizování zažitých představ o smrti jako o tabuizovaném sociálním jevu.

\section{Sociální řád}

Smrt jako sociální fenomén se v předsociologickém ani sociologickém myšlení zhruba do poloviny 20. století př́liš často neobjevuje. ${ }^{2}$ Zpravidla je pojímána jako přirozená součást

* PhDr. Lenka Beranová, STEM/MARK, Na Hrázi 17, 18000 Praha 8. E-mail: beranova.1@gmail.com

1 Revivalismus je určitý myšlenkový proud v sociálních vědách, který věří, že smrt v pozdní modernitě není jen popírána a tabuizována, ale naopak, že v jistém ohledu „slaví“ návrat (z angl. revival - návrat).

2 Jistou výjimku tvoří Masarykova monografie Sebevražda, poprvé vycházející německy v roce 1881. 
života, kterou ovšem jedinec zakouší jako „mezní situaci“ [Berger in Howarth 2007: 89]. Zároveň je smrt chápána jako ohrožení společnosti, které je proto potřeba legitimizovat souborem norem a rituálů, aby se zachoval sociální raád. Tento sociální význam smrti se do zorného úhlu sociálních věd sice dostal, ale zde sloužil spíše jako nástroj pro vysvětlení některých obranných mechanismů společnosti. V sociologii se proto otázka smrti objevila jen nepřímo, zejména $\mathrm{v}$ rámci studia sociálního řádu, společenských norem a hodnot.

V této souvislosti se smrt považovala za hlavní zdroj náboženské víry [Malinowski 1962 in Walter 1993: 273]. Složité sociální změny, jež měly za následek nárůst určitých životních jistot a kvality života, včetně pokroku medicíny, také způsobily, že se do značné míry snížila, dříve všudypř́itomná a každodenní hrozba smrti. Smrt přestala být všednía „,skryla“ se [Blauner in Přidalová 1998]. V návaznosti na Bronislawa Malinowského se v rámci sociologie náboženství objevila hypotéza, že sekularizace společnosti úzce souvisí také s tímto ústupem smrti. Klesající vliv náboženství na všední život se totiž vysvětloval „poklesem strachu ze smrti, který vedl ke snižování strachu z pekla“ [Walter 1993: 273].

Smrt se začíná problematizovat poněkud paradoxně právě v době, kdy jednotliví aktéři přestávají být každodenně vystaveni nejistotě o svůj život i životy svých blízkých. Přibližně od 60 . let 20 . století se totiž začaly množit kritické ohlasy, které v převládajícím postoji, jaký společnost zaujala ke smrti, spatřovaly cosi nového a škodlivého [Přidalová 1998]. Tím, že se smrt stává výhradní doménou medicíny, se tato problematika do značné míry přesouvá z intimního prostředí blízkých do úzké sféry specialistů. Tady se smrt chápe jako problém, který je potřeba odstranit. Kritizována byla zejména absence účinného obranného mechanismu, který by společnosti umožnil, aby se s faktem smrti vyporáalala jinak než jejím vytěsňováním. Výstižně vztah moderní společnosti a smrti popsal antropolog Geoffrey Gorer, který v roce 1955 přispěl do diskuse výrazem „pornografie smrti“3 [Littlewood 1993].

\section{Sociologické výzkumy na pozadí medicinalizace ${ }^{4}$}

Pomineme-li sociologii náboženství, kde se problém smrti nepřímo objevuje, tematizuje

Masaryk se zde zamýšlí nad obecnými vlivy, jež mohou dovést jedince k sebevraždě. Zároveň uvažuje o vztahu společnosti k sebevražednosti a nastiňuje dějinný vývoj sebevraždy jako sociálního jevu, který koncem 19. století zaznamenal určitý vzestup. Masaryk dochází k názoru, že hlavní příčinu nárůstu sebevražd je třeba spatřovat v sekularizaci. V této souvislosti nelze opomenout ani Durkheimovu studii Le Suicide [1897]. Sebevraždy Durkheim chápe také jako do určité míry sociální, nikoli individuální jednání. Nicméně centrálním tématem je pro něho přechod tradiční společnosti k moderní a z toho vyplývající často pocitovaná anomie. Téma sebevraždy se později objevuje v dílech dalších autorů [Halbwachs 1930, Berd’ajev 1931, Blondel 1933 a další], podle A. I. Bláhy však už Masaryk jako jeden z prvních dokázal postihnout celou rozsáhlou podmíněnost sebevražednosti jako sociálního jevu [Bláha 1997: 39]. Zmíněné práce sice dokládají určitý zájem sociologie o problematiku smrti, nicméně v její úzké a v jistém smyslu i extrémní formě. Sebevražednost studuje jak Masaryk, tak Durkheim jako důsledek rozmanitých sociálních změn, ale nezabývají se přímo problémem smrti.

3 „Pornografie smrti“ v mnohém připomíná dřívější vztah společnosti k sexu. Podobně jako v 18. a zejména 19. století panovala všeobecná rezervovanost ve vztahu ke všemu tělesnému, tak se v období přibližně po druhé světové válce tato tabuizace obrací ke všemu, co souvisí se smrtí a umíráním.

4 Medicinalizace - proces, který podle Illicha představuje prorůstání medicíny do ostatních sfér společnosti, implicitně i do života jedince. Mnohé problémy a jevy se nově skrze medicínu tematizují, a určují tak hranice mezi normou a deviací. Aktér postupně ztrácí suverenitu a autonomii v domnění, že si bez pomoci medicíny, resp. odborníků, sám neporadí. Na příkladě bolesti Illich ukazuje, jak se pod vlivem medicínského paradigmatu problematizuje bolest při porodu, kterou je potřeba omezit namísto toho, aby se chápala jako přirozená, i když nelehká součást života [Illich 2002]. 
smrt až sociologie medicíny, a to zejména ve svém druhém, tzv. post-parsonovském období, které je k medicíně mnohem kritičtější. Předchozí éra, ovlivněná parsonsovským paradigmatem, totiž spíše moc medicíny ve společnosti upevňuje: jednak důrazem na pojetí medicíny jako sociální kontroly, jednak „přispíváním k šírení její pozitivní image“ jakožto „jednoho z klíčových symboli̊ úspěchů moderní společnosti“ [Křžžová 2003: 124]. Od 60. let se tato myšlenková linie opouští a prostor získávají spíše ti, kdo v organizaci medicíny naopak reflektují problémy např. Illich [2002], Kübler-Rossová [1993], Sudnow [1967], Glaser a Strauss [1965].

Pro tematizaci umírání v sociologii byly zásadní zvláště výzkumy, které se zaměřovaly na vztah lékaře nebo ošetřujícího personálu a pacienta. Tato zkoumání se zpravidla zaměřovala na otázku komunikace a problematiku sdělování diagnózy. Walter [1993] zájem těchto výzkumů rozděluje do dvou hlavních skupin. První se soustředuje na otázku, jak a do jaké míry jsou pacienti a jejich blízcí příbuzní zpraveni o terminální (smrtelné) diagnóze, druhá se pak dotýká přímo procesu umírání.

Do první skupiny lze zařadit výsledky výzkumu publikované pod názvem Awareness of Dying. Sociologové Glaser a Strauss [1965] zde identifikují několik způsobů, jak je pacient konfrontován s diagnózou. Jednotlivé typy se liší hlavně tím, nakolik si je vědom svého stavu. ${ }^{5}$

Mezi důležité výzkumy vztahující se přímo k procesu umírání patří práce psycholožky Elisabeth Kübler-Rossové [1993]. Její teorie o stádiích (šok, agrese, vyjednávání, deprese, smíření), jimiž prochází umírající a jeho blízké okolí, patří mezi klasické práce v této problematice. Význam Kübler-Rossové spočívá hlavně v otevření zájmu o situaci umírajících, jak na akademickém poli, tak ve veřejné diskusi. ${ }^{6} \mathrm{O}$ něco méně známé, přesto důležité a ve své době hodně kritické, byly další práce sociologů Glasera a Strausse [1968] o „trajektoriích umírajících“ nebo Rothova koncepce časových rozvrhů [1963], kterými je proces umírání institucionálně řízen [Walter 1993: 269]. Také Sudnowova kritika organizace umírání v nemocnicích [1967] s důrazem na rutinu, která formuje pevné a hladké fungování běžného chodu těchto institucí [Littlewood 1993: 71], patří mezi významné práce. ${ }^{7}$

5 Glaser se Straussem používají termín „kontexty uvědomění“. Za prvé jde o kontext „uzavřený“. Lékař a rodina spolupracují, aby před pacientem skutečnost utajili. Za druhé rozlišují kontext, kdy pacient zkouší různé taktiky, aby se pravdy nějak dopátral, např́klad od personálu nemocnice. Tento kontext nazývají „podezření“. Dalším častým případem je tzv. „oboustranné předstírání“, o kterém mluvíme, pokud obě strany tzn. lékař a rodina na jedné a pacient na druhé straně, vědí o blížícím se a neodvratném umírání, ale žádná z nich nechce tu druhou stranu zneklidnit a rozrušit vlastním vědomím této skutečnosti. Zbývající situace - „otevřený kontext“ - připouští zcela otevřenou diskusi mezi všemi zúčastněnými o zdravotním stavu a případných perspektivách a možnostech [Walter 2005: 31, Bártlová 2005].

6 Nemalý vliv se Kübler-Rossové přičítá v začátcích hospicového hnutí na konci 60. let, ve kterém důležitou roli sehrála společně se zakladatelkou prvního hospice Cicely Saundersovou. Skutečnost, že vůdčími osobnostmi hospicového hnutí byly právě ženy, podle Waltera nebyla náhodná. Ženy k problematice přistupovaly jinak než muži, kteří reprezentovali spíše racionalizaci a medicinalizaci. Pávě tento odlišný prrístup podle něj přirozeně vyústil v hospicové hnutí [Walter 2005: 13].

7 Sudnow dospěl k závěru, že i ve smrti do jisté míry fungují mechanismy sociální nerovnosti. Zjistil, že lékaři neuplatňují oživovací procedury u všech podobně postižených pacientů stejně, ale provádějí určitý výběr. Lidé z nejnižších sociálních vrstev, u nichž se dalo předpokládat, že jsou např́iklad drogově závislí, alkoholici, bezdomovci nebo prostitutky, byli za mrtvé prohlášeni dříve, zatímco těm, co byli považováni za bohaté, mladé, s domnělou vyšší sociální prestiží, bylo podle Sudnowa věnována nesrovnatelně více úsilí při oživování [Turner 2006: 123]. 


\section{Tělo a tělesnost $\mathbf{v}$ sociologii}

Od 80. let je viditelným trendem v sociálních vědách narůstající zájem o tělo a tělesnost. V sociologii jde o téma poměrně nové, nenajde se totiž explicitně vyjádřené v žádné klasické sociologické teorii. ${ }^{8}$ Přesto podle Shillinga bylo tělo v sociologii vždy, i když jaksi „nepř́tomně př́tomno“ (absent presence) [2004: 17].

Za zakladatele samostatné subdisciplíny „sociologie těla“ je považován Bryan S. Turner9 s prací The Body and Society [1984]. Tělo podle Turnera není bezvýhradně jen fenoménem přírodních věd, nýbrž musí být nutně chápané také jako produkt kultury, potažmo společnosti. Lidské tělo má proto jako sociální jev své dějiny a zahrnuje také určitý vztah, který zaujímá ke svému tělu jedinec v dané společnosti. Sdílené představy o kráse a zdraví i měnící se význam těla ve společnosti totiž mohou být např́č různými kulturami proměnlivé, což je důkazem, že fenomén těla nelze redukovat na biologickou danost. Podle Turnera [1992] je tělo „možností utvárenou kulturou a realizovanou v průběhu lidských interakcí“ [Turner in Bauman 1995: 68]. Skutečnost, že je lidské tělo nově pojímáno také jako produkt společnosti, tzn. že je vytvářeno sociálně, kulturně a historicky, v sobě zahrnuje dvě kvality. Jednak je samo tělo „produktem“ ve smylu hmotného ztělesnění etnicity, rasy, genderu, věku a současně také prostorem pro předvádění osobních identit, krásy, zdraví, image atd. Za druhé je tělo „procesem“, což zahrnuje specifický způsob poznávání a hodnocení světa, stejně jako poznávání a hodnocení sebe samého [Balsamo 1997: 3].

Zatímco ve středověké kultuře bylo tělo ve prospěch duše spíše potlačováno, v moderní společnosti se tato relace obrátila. A s prohlubujícím se individualismem v druhé polovině 20. století vztah jedince k vlastnímu tělu ještě zesílil. Tělo se nově formulovalo jako subjekt a současně i objekt při tzv. sebe-projektování. Ztotožnilo se tak s zhmotněním „já“ (self), které lze chápat jako určitý program a záměr individualizace [Shilling 2004]. Současné debaty týkající se těla a individualizace často vycházejí z argumentu, že kontrolu těla - potažmo jedince, zajištuje jedinec sám prostřednictvím konzumu a módního průmyslu. Podle Featherstona dnešní význam těla reflektuje nově se objevující tzv. „předvádějící se já“ (performing self), u něhož jsou „vzhled, gesta a vůbec vystupováni celého těla považovány za sebe-vyjádření, i s fyzickou nedokonalostí a nepozorností, které prinášeji jistá znevýhodnění v každodenních interakcích" [Featherston in Howarthová 2007: 179].

V sociologii tyto úvahy odkazují na Goffmanovu práci o sociálním stigmatu, kdy míra traumatu z vlastního vzhledu vychází z míry rozdílnosti mezi „virtuální sociální identitou“ a „skutečnou sociální identitou“ [Goffman 2003]. Podle Shillinga je v podmínkách pozdní modernity „tendence jedinců více vázat svou osobní identitu (self-identity) ke svému tělu. Z tohoto hlediska, ačkoli [zveličeně], je relevantní Goffmanova analýza stigmatu, když naznačuje, že jedinec smysl svého 'já' pravděpodobně postihuje posuzováním ceny svého těla“ [Shilling 2004: 161].

8 Za jednu z hypotéz, proč se klasická sociologie nezajímala o zkušenost „mít“ a „být“ tělo, je Shillingem možná poněkud provokativně označen prostý fakt, že mezi zakladateli sociologie chyběla žena. „Rizika, kterým ženy čelily během těhotenství, velké množství těch, co zemřely při porodu a vysoká míra dětské úmrtnosti, která charakterizovala průmyslovou revoluci by možná byla reflektována prostrednictvím větších úvah o těle, kdyby Marx, Simmel, Weber a Durkheim byli ženami [Shilling 2004: 24].“

9 Zásluhou Turnera (1992) tedy pozdně moderní společnosti přibyla další z mnoha nálepek [Petrusek 2006] jakožto „společnost somatická“. Jde o společnost, kde se „hlavní politické a osobní problémy problematizuji skrze tělo a současně se také prostřednictvím těla vyjadřují“ [Turner 2004: 1]. 
Protože je v pozdně moderní společnosti do značné míry věcí jedince, jak si vytvoří svou osobní identitu, ${ }^{10}$ chce si přirozeně udržet co možná nejdéle jistý vliv nad dějem, který prožívá. Lépe řečeno se snaží neztratit kontrolu nad výkladem situace, která se ho přímo dotýká. Jelikož na něm samotném leží tíha odpovědnosti z možného selhání při sebe-projektování, nejvíce se obává ztráty této kontroly. Nemoc a smrt jsou jedním z nejzásadnějších narušení osobní identity také z toho důvodu, že představují postupné tělesné chátrání a ztrátu schopnosti ovládat vlastní tělo. To znamená, že je vážně ovlivněna účast na „sebe-předvádění“ [Featherstone 1995]. Při procesu postupného fyzického úpadku a v rámci sociální smrti ztrácí do jisté míry svou osobní identitu. Neděje se tak z důvodu, že by mizely nějaké konkrétní rysy či charakteristické vlastnosti, které jedinci patří. V Giddensově pojetí osobní identity se tak děje proto, že selhává schopnost jedince reflexivně porozumět vlastnímu „já“ z hlediska své biografie [Giddens 1991]. Osobní identita přepokládá, že aktér reflexivně interpretuje svou souvislost v čase a prostoru, i to, jak je interpretován ostatními. V případě vážné nemoci je toto narušeno.

Podle některých teoretiků [Featherstone a Hepworth 1991; Shilling 1993] dochází v době nemoci k částečnému oddělení „já“ (self), implicitně i vnímání těla, od výsledné sociální identity, viditelné pro ostatní. Zatímco jiní interpretují identitu skrze nemocné tělo, ta může být pro nemocného jedince neautentická [Howarth 2007: 181]. Jinými slovy může dojít k fragmentizaci „já“ zásluhou nedostatečného překrytí mezi „mou identitou“ a „vaším“ vnímáním mé identity na základě mého nemocného těla, což nutně vede k potřebě nově uspořádat vlastní identitu [Howarth 2007:181].

Krajním případem je pak totální ztráta „já“ (self), která se projevuje jako úplné mentální „vypnutí“. Jedinec odmítá reagovat s okolím, přestává být sám sebou. ${ }^{11}$ Podle Julie Lawtonové [1998], jejíž studie se zabývá sociálními důsledky tělesného úpadku umírajících, je tato totální ztráta „já“ častá v př́ípadech obyvatel hospiců, kteří nejsou schopni zvládat některé projevy svého nemocí viditelně zasaženého těla. ${ }^{12}$ Zatímco při fragmentizaci se „já“ oddělí a jaksi distancuje od těla, v případě mentálního „vypnutí“ dochází k úplnému zmizení „já“ a tělo dále přežívá „prázdné“. Lawtonová uvádí, že někteří pacienti, u kterých tento proces neprobíhá samovolně, žádají o silná sedativa a v krajním př́padě o eutanázii [1998: 128]. Důvodem bývají pocity trapnosti a studu, nikoli fyzická bolest. Lawtonová se domnívá, že „identita a osobnost jedince v současné západní společnosti je fundamentálně závislá na vlastněni fyzicky ohraničeného těla" [Lawton 1998: 131]. Podobný názor sdílí také Chris Shilling, když ř́ká, že „v podmínkách pozdní modernity se projevují tendence, které $z$ těla stále více činí podstatu pocitu osobní identity moderního jedince" [2004: 1]. Nevyhnutelně i perspektiva smrti nějakým způsobem

10 Osobní identitu (self-identity) Giddens definuje jako „releflexivní já“; „není to nic, co by bylo dáno, (...), nýbrž cosi, co musí být rutině vytváreno a udržováno v reflexivních aktivitách jedince [Giddens 1991: 52].

11 Koncept „vypnutí“ (switching off)se také někdy označuje jako psychická smrt. Pines o ní hovoří v případě vězňů koncentračních táborů, „které přemohla fyzická a citová bezmocnost a zoufalstvi““ (Pines 1993 in [Lawton 1998: 130]).

12 Lawtonová pracuje s pojmy „ohraničeného“ bounded těla ve smyslu ovladatelného a „neohraničeného“ unbounded těla jako takové, které svými nekontrolovatelnými projevy narušuje integritu jedince. Podle Lawtonové personál hospiců pro tento stav používá metaforu „rozpadat se ve švech“ (falling apart at the seams) [Lawton 1998: 128]. Jde o př́ípady, kdy je nemocný „vyžírán nádorem“, „uhnívá zevnitř̌“ [Lawton 1998: 128]. Nejčastěji se projevují inkontinencí, nekontrolovatelným zvracením, silným zápachem, otékajícími končetinami atd. 
ovlivňuje naše současné chápání těla [Shilling 2004: 1] a pro sociologii těla tak představuje jeden z klíčových problému. Vznik samostatné subdisciplíny „sociologie umírání a smrti“ lze proto také částečně chápat jako přirozený důsledek vývoje uvnitř jiných disciplín a sociologie těla obzvlášt.

\section{Sociologie smrti}

Na počátku 90. let se začínají objevovat otázky, zda se o fenomén smrti nadále zajímat jen parciálně v rámci jednotlivých jiných oblastí sociologie či zda již neuzrála doba, která by si žádala samostatnou subdisciplínu. Tato debata vyvolala i úvahy, kam by se dále sociologie měla ubírat [Mellor 1993; Walter 1993]. Fenomén smrti na pozadí sociálních změn totiž sociologii může posloužit k analýze a bližšímu porozumění jiných společenských jevů a problémů, a proto by se tento potenciál neměl nechat nevyužitý. ${ }^{13}$

Britský sociolog Tony Walter v roce 1993 shrnuje v článku Sociologists never die: British sociology and death dosavadní příspěvky k tématu smrti a umírání a dospívá k názoru, že dozrál čas hlouběji reflektovat význam smrti ve společnosti. Walter svůj text provokativně uzavírá otázkou „sociologie smrti, nebo smrtelná sociologie?" [Walter 1993: 290]. Na druhé straně však může se vznikem samostatné specializace „sociologie umírání a smrti“ hrozit nebezpečí jisté konzervace myšlení, kterému je obtížné se bránit. V případě většího seskupení sociologů se zájmem o otázky umírání totiž hrozí jistá „izolace od hlavních proudů oborového zájmu“" [Clark - Seymour 2002: 9].

Úkolem sociologie by mělo být objasnění sociálních a kulturních faktorů a zkušeností, které tvoří rámec pro současné postoje k lidské smrtelnosti [Mellor 1993: 26]. Pokud přijmeme tezi, že smrt je dnes vyvlastněna z veřejné sféry, pak by sociologie smrti měla vysvětlovat souvislost mezi tímto vyvlastněním s reflexivitou pozdně moderní společnosti. Tato reflexivita podporuje privatizaci smyslu, což může ohrožovat pocit Giddensova „ontologického bezpečí“. Nová subdiciplína by tedy podle Mellora měla navazovat na sociologickou tradici, zároveň ale také rozšiřovat sociální teorii o nové směřování. Mellor zdůrazňuje, že pokud sociologie smrti do svého teoretického programu neintegruje vedle smrti také život, stane se jen exotickou akademickou specializací, institucionalizovanou sociologickou subdisciplínou, která díky svému marginálnímu postavení k podstatným sociologickým debatám může nabídnout jen omezené výklady fenoménu smrti. Sociologie smrti se má naopak orientovat na aktuální problémy a skrze smrt se soustředit na vysvětlení tenze mezi absencí smrti ve veřejné sféře a její přítomnosti ve sféře soukromé, čímž by významně přispěla $\mathrm{k}$ diskuzím o pozdní modernitě [Mellor 1993: 28]. ${ }^{14}$

13 V kontextu debat o potřebě silněǰí reflexe role umírání v sociologii nelze přejít bez povšimnutí to, co přibližně ve stejné době pravděpodobně nezávisle na těchto diskusích, u nás piše sociolog rodiny Ivo Možný: „Podle současných zvyklostí bychom v knize o rodině vůbec neměli psát o umírání. A pokud, tak až v souvislosti se stárím a tuto kapitolu bychom měli zařadit až na konec knižky. Patř́ však na začátek. Dotkneme se v ní snad všech témat, o kterých budeme mluvit později. Někde se budeme i opakovat. Zdá se nám však podstatné vysvětlit hned na začátku, co všechno naše témata spojuje. Kdybychom to neudělali a zůstali jen na tom, že u každého z nich zmíníme, jak je častá a všudyprítomná smrt v rodině ovlivnila, mohlo by nám uniknout, že právě ona působila jako jeden z nejvýznamnějších jednotících motivů rodinného života, který udával rytmus veškerého dění. Tíz by se nám pak naše téma chápalo $v$ celku, který jen nezbytnost postupného výkladu rozděluje na kapitoly [Možný 1990: 31-32].“

14 Uplynulých přibližně patnáct let od počátků konstituování této sociologické subdisciplíny je zatím poměrně krátkých na nějaké hodnocení, nicméně by bylo dobré zmínit, že ve Velké Britanii bylo v záríí 


\section{Revivalismus a neo-moderní smrt}

Diskuse o umírání v podmínkách moderní společnosti se vedou ve dvou hlavních směrech. První představují ti, podle kterých jsou otázky umírání a smrti tabuizované [Ariès 2000; Gorer 1955; Kübler-Rossová 1993; Elias 1998]. Druhý směr reprezentují ti, kteří naopak s ideou tabuizace smrti jako univerzální charakteristiky moderní společnosti nesouhlasí. Mezi ně Přidalová zařazuje Waltera, Blaunera, Dumonta a Fosse [Přidalová 1998: 348]. ${ }^{15}$

Další debaty významně ovlivnil „revivalismus“, s nimž v 90 . letech přichází britský sociolog Tony Walter. Obohacující je na tomto přístupu zvláště neredukování celé diskuse kolem umírání a smrti na tradiční versus moderní, tzn. dobrá smrt versus její negace. Tony Walter se neohlíží nostalgicky po tradičních pořádcích a zdůrazňuje nesporný nárůst kvality života, jež přinesla moderní společnost a dodává: „Raději bych umřel v tomto století s jeho lékařskou péčí, než kdykoli předtím (...) zároveň ale s moderní byrokracií a úspěchy v medicíně existuje bolestivý konflikt. A právě tento konflikt motivuje snahu obnovit smrt v nové formě [Walter 2005: 22]. "Hledání nového modelu smrti tak, aby spojoval to dobré z podmínek umírání v tradiční a moderní společnosti a zároveň co je nejlépe odpovídal potřebám silně individualizovaného jedince v pozdně moderní společnosti, je pro revivalismus zásadní tezí. Východisko nachází v tzv. neo-moderním modelu smrti.

Klíčovou revivalistickou prací je kniha Tonyho Waltera The Revival of Death, poprvé publikovaná v roce 1994. Britský sociolog zde srovnává, jakým způsobem zasahuje charakter fyzické smrti do organizace smrti jako sociálního faktu v dané společnosti. Smrt jako socio-kulturní fenomén totiž není neměnná. Je ji proto třeba interpretovat vždy v daném kulturním a sociálním rámci. Umírání se může v jednotlivých společnostech odlišovat nejen v př́činách, ale také jiným obranným mechanismem společnosti, různým uvažováním o smrti a v neposlední řadě také odlišným strachem ze smrti. V rámci dané kultury a společnosti lze vytvořit jakési typy převažujícího způsobu umírání a zároveň i jakéhosi panujícího ideálu, které zpětně umožní teoreticky a později i prakticky reflektovat skutečnost. Vedle toho ale nelze opomíjet, že umírání každého jedince je jedinečné a „každý umírá svou smrtí“ [Haškovcová in Vorliček 2004: 435]), proto všechny zmiňované typy smrti představují vždy jen tendence k určitým modelům, které slouží více jako heuristický nástroj dalších analýz a hypotéz než jako odraz skutečnosti [Walter 2005: 47; Clark, Seymour 2002: 12].

2005 na Univerzitě v Bath založeno „Centrum pro smrt a společnost“ (CDAS - „Centrum for Death and Society“) jako interdisciplinární středisko zabývající se teoretickým studiem i empirickým výzkumem všech sociálních aspektů smrti a umírání. Význam tohoto centra je nejen regionální a národní, ale také mezinárodní. Mezi jeho členy vedle Glennys Howarthové nebo Tonyho Waltera, také Allan Kellehear, Une MacConville a další. Z hlediska sociologie smrti a umírání je také důležité pořádání „International Conference on the Social Context of Death, Dying and Disposal (DDD) “ mezinárodní konference zabývající se sociálním kontextem smrti a umírání, která se organizuje pravidelně jednou za dva roky. Ta zatím poslední,v pořadí osmá, proběhla v září 2007 v Bathu.

15 Blauner se domnívá, že tabuizace smrti souvisí s věkovou strukturou moderních společností, a spíše než tabuizovaná je proto ve skutečnosti skrytá mezi starší populací. S ohledem na věkovou strukturu zemřelých prý dnes také není smrt blízkých tak silnou ztrátou a zásahem do našeho života. Naráží tím na skutečnost, že pokud dříve častěji než dnes umírali lidé v produktivním věku, ,zanechávali po sobě obrovskou sociální, ekonomickou a psychologickou trhlinu predevším v rodinách, které byly na zemřelých ve všech těchto ohledech závislé [Přidalová 1998: 349]." Dumont a Foss jsou zase zastánci tvrzení, že strach ze smrti a umírání je přirozený všem lidem ve všech společnostech [Přidalová 1998]. Jednotlivé společnosti se jen liší v obranných mechanismech. 
Ústředním tématem revivalistů je tedy neo-moderní model smrti, který se stejně jako tradiční a moderní modely nevznáší v sociální realitě, nýbž je zakořeněný v daném sociálním kontextu a konkrétním kontextu těla, které společně umožňují určitou strukturu autority [Walter 2005: 47]. Tyto tři složky, tzn.: sociální kontext, kontext těla a autorita, tvoří podstatu Walterovy komparace.

\section{Typologie smrti}

\begin{tabular}{|c|c|c|c|}
\hline & TRADIČNÍ & MODERNÍ & NEO-MODERNÍ \\
\hline \multicolumn{4}{|l|}{ KONTEXT TĚLA } \\
\hline archetypální smrt & mor & rakovina / infarkt & rakovina / AIDS \\
\hline trajektorie umírání & rychlá & skrytá & prodlužovaná \\
\hline naděje dožití & 40 & 70 & 80 \\
\hline vidět jiné umírat & často & zřídka & $\begin{array}{l}\text { být svědkem umírání, } \\
\text { ne smrti }\end{array}$ \\
\hline „human condition“ & život se smrtí & smrt kontolováná & život s umíráním \\
\hline typická smrt & v dětství & v pokročilém věku & v pokročilém věku \\
\hline sociální zrození & $\begin{array}{l}\text { následuje po } \\
\text { fyzickém narození }\end{array}$ & $\begin{array}{l}\text { v okamžiku fyzického } \\
\text { narození }\end{array}$ & $\begin{array}{l}\text { předchází fyzickému } \\
\text { narození }\end{array}$ \\
\hline sociální smrt & $\begin{array}{l}\text { následuje } \\
\text { po fyzické smrti }\end{array}$ & $\begin{array}{l}\text { předchází } \\
\text { fyzickou smrt }\end{array}$ & $\begin{array}{l}\text { v okamžiku } \\
\text { fyzické smrti }\end{array}$ \\
\hline netypická smrt & ve stáří (uctívaná) & v mládí (nesmyslná) & v mládí (nesmyslná) \\
\hline \multicolumn{4}{|l|}{ SOCIÁLNÍ KONTEXT } \\
\hline sociální struktura & společenství & veřejné vs soukromé & $\begin{array}{l}\text { soukromé a veřejné se } \\
\text { vzájemně prolínají }\end{array}$ \\
\hline osobnost & sounáležitost & identita & identity \\
\hline nalezená v & společenství & rodině & vztazích \\
\hline smrt = ztráta & sociální pozice & jedné indetity & více indentit \\
\hline úkoly po smrti & rekonstrukce rolí & $\begin{array}{l}\text { rekonstrukce } \\
\text { jedné identity }\end{array}$ & $\begin{array}{l}\text { rekonstrukce více } \\
\text { identit }\end{array}$ \\
\hline realizováno skrze & smutek (mourning) & žal (grief) & $\begin{array}{l}\text { vyrovnávání se } \\
\text { (grief work) }\end{array}$ \\
\hline \multicolumn{4}{|l|}{ AUTORITA } \\
\hline autorita & $\begin{array}{l}\text { Bůh / tradice } \\
\text { - vůle Boží }\end{array}$ & $\begin{array}{l}\text { lékařská odbornost } \\
\text { - nařízení lékaře }\end{array}$ & $\begin{array}{l}\text { já (self) - } \\
\text { „Udělat po svém.“ }\end{array}$ \\
\hline známá skrze & kněz (muž) & lékař (muž) & poradce (žena) \\
\hline instituce & kostel & nemocnice & domov / hospic \\
\hline smysl & dán & zrušen (ve veřejném) & $\begin{array}{l}\text { vytvářen } \\
\text { interpersonálně }\end{array}$ \\
\hline Náboženství & dáno & volba církve & vnitřní spiritualita \\
\hline
\end{tabular}

mírně upraveno dle Walter 2005: 48

Vychází přitom z označení „archetypální smrti“, pod čímž rozumí jednu z častých příčin úmrtí s ohledem na průběh umírání, který je pro danou společnost charakteristický. Např́íklad infekční nákazy naprosto nekontrolovatelně, náhle a poměrně rychle „zabíjely“ všechny věkové kategorie. Zde je zastupuje mor jako archetypální smrt v tra- 
diční společnosti. Situace se mění v moderní společnosti, kde se spolu s pokrokem v medicíně neustále snižuje počet životu nebezpečných virových onemocnění a zároveň se zvyšuje kvalita života. Tato rozsáhlá sociální změna výrazně proměnila demografickou strukturu obyvatelstva. Jednak se výrazně snížila kojenecká a dětská úmrtnost, která představovala nejvyšší míru úmrtí, jednak se celkově snížil počet úmrtí v průběhu produktivního života a úmrtnost se přesunula k vyššímu věku života, což také ilustrují kategorie typické a netypické smrti. Zatímco v tradiční společnosti byla dětská úmrtnost mnohem vyšší než dnes a ženy rodily více dětí už s vědomím, že se většina $z$ nich nedožije dospělosti, v moderní a v současné západní společnosti věc spíše ojedinělá, a proto je taková smrt označována za nesmyslnou, marnou apod. V tradiční společnosti však byla zcela běžnou, a proto ani vztah rodičů k dětem nemohl být tak silný a vřelý, emočně by nebylo únosné smrt tolika dětí psychicky zvládnout [Možný 1990].

V souvislosti s otázkami „sociálního zrození“ a „sociální smrti“ se o smrti uvažuje ještě více jako o sociálním faktu. V tradiční společnosti sociální zrození a smrt vždy následují až po biologickém narození či smrti, v obou dalších typech je to ale odlišné. V moderní společnosti je „sociální narození“ totožné s fyzickým, ale v neo-moderní už je jistý zjevný posun, sociální stránka předchází fyzickou. Př́činy lze hledat v proměnách kvality života. Rozširrení antikoncepce přineslo nejen možnost vyvarovat se nežádoucího otěhotnění, ale současně také větší plánování potenciálních děti. Ještě nenarozeným dětem se často připisuje určitá identita dlouho před porodem, k čemuž přispívá také lékařská technologie, když dokáže pořídit obraz zárodku v děloze. ${ }^{16}$ Identita dospělých se zde částečně definuje také jako rodičovská skrze ještě nenarozené děti, skrze jejich prenatální život. Sociálně jsou tedy často tyto děti narozené ještě před svým fyzickým na-rozením, které nemusí být naplněno. Podle Daviese jsou v takovém př́ípadě dnes tendence alespoň na chvíli „propůjčit“ mrtvě narozeným nebo brzo po porodu zemřelým dětem „status živých“ tím, že jsou pokřtěny nebo že se s nimi jejich matky nechávají vyfotografovat [Davies 2007].

Opačně je tomu v případě vztahu fyzické a sociální smrti. Termín sociální smrt se začal používat pro označení stavu terminálně nemocných pacientů v komatu. V nejširším vymezení však pod tímto pojmem rozumíme zužování sociálních interakcí, vazeb a rolí z důvodu jisté stigmatizující situace, kterou přinášejí zjevné i méně zjevné znaky nevyléčitelné nemoci. Jedinec vyvázaný ze svého důvěrně známého prostředí může být postupně redukován hlavně na roli pacienta, popř. diagnózy. Ona zmíněná „vyvázanost“ se nemusí dotýkat jen přímé hospitalizace, ale častěji se projevuje již dříve řídnutím společenských kontaktů. Také rodina se může potýkat s problémem komunikovat s nemocným jako dřív, nebơ „jazyková zásoba pro takové situace je poměrně omezená. Trapné

16 Podle religionisty Daviese „takové zobrazování promění zárodek $v$ „dítě“, a pěstuje tak prèedstavu o jeho identitě dlouho před narozením. (...) oproti dřivějším zvyklostem některé nemocnice umožňují matkám nebo oběma rodičům, aby se nechali vyfotografovat se svým mrtvě narozeným dítětem anebo dítětem, které zemřelo krátce po porodu. Žena tak může nabýt pocitu sebe jakožto 'matky: Takovou 'smrt' dítěte tudiž společnost jaksi zaznamenala a rituálně se s ní vypořádala, ačkoli dř́ve by se $v$ takovém př́padě mohlo stát, že by se hovořilo o 'biologickém odpadu' [Davies 2007: 44-45]." Potrat či porod mrtvého dítěte nebo smrt novorozeněte těsně po porodu, jak o nich uvažuje Davies, zde uvádíme jako ilustraci neo-moderní situace, kdy sociální zrození předchází fyzickému narození. Ačkoli se v jednom případě jedná o smrt, uvažujeme o všech jmenovaných prrípadech spiše jako o fyzickém „nenarození než jako o fyzické smrti. 
pocity zabraňují živým promluvit." [Elias 1998: 24]. V důsledku toho dochází k situaci, kterou Elias označil jako „osamělost umírajících“ [1998].

Zatímco v moderní společnosti sociální smrt předchází fyzickou, což bylo také zdrojem mnoha kritik moderního způsobu umírání [Elias 1998; Ariès 2000; Kübler-Ross 1993], v neo-moderním případě k sociální smrti dochází až v momentu fyzické smrti. Zde se totiž předpokládá, že jedinec neumírá osamělý, ale v kruhu svých blízkých, kteří „mu rozumějí“. Moment porozumění individuálním potřebám umírajícího je pro neo-moderní smrt zásadní. Ruší se tím i jisté odcizení smrti, které je zakoušené v př́ípadě moderní medicinalizované smrti [Illich 1976]. Jedním z mnoha impulsů, který mohl vést k posunu z moderní k neo-moderní smrti, může být v jistém smyslu fakt, že se nežije se smrtí jako s okamžikem, ale s umíráním jako procesem. Tuto novou zkušenost podle Waltera poněkud zhuštěně vystihují slogany „žit s rakovinou“ nebo „žít $s$ HIV“ [Walter 2005: 50]. Zásluhou pokroku v diagnostice lze totiž odhalovat neléčitelné smrtelné choroby v stále ranějších fázích, a tak teprve před deseti či dvaceti lety začalo docházet „k posunu ze společnosti, jejíž členové odmítali uvažovat o své smrtelnosti nebo jim byly odepřeny všechny př́ležitosti o smrti premítat, ke společnosti, kde značná část lidí ve středním věku či starších ví, že oni nebo jejich blizcí př́buzní onemocněli život ohrožující chorobou, která je nemůže zabít během pár let, ale v jejiž stínu budou muset žít“ [Walter 2005: 50].

Rozvoj diagnostiky lze tedy chápat jako jednu z mnoha přičin trendu zesilování potřeby nevyléčitelně nemocných podílet se, po konzultacích s odborníky, na rozhodovaní o průběhu léčby a péče. Autoritu lékaře tak v neo-moderním typu smrti má stále více nahrazovat autorita individuálních prání, tedy prosazování ideje „udělat si po svém“. Zájem soukromého se v silně individualizované společnosti stává částečně rovněž sférou veřejnou, což se projevuje také v budování veřejných institucí (např. hospiců), které mají svůj účel provádět tak, aby podporovaly sebe-vyjádření každého jednice. Na pozadí některých procesů se tedy může měnit nejen forma, ale také obsah smrti a umírání.

Ve společnostech, kde je identita více zakotvena v komunitě, v rodině nebo nějaké jiné skupině, je strach ze smrti především obavou o přežití této skupiny [Walter 2005: 16]. V současné západní společnosti dochází k jitému posunu a vlastní smrt stává v něčem problematičtější. Podle Waltera „se smrti bojíme, protože se obáváme ztráty sebe“ [Walter 2005: 16]. Strach z vlastní smrti lze chápat opět pod vlivem individualizace o něco niterněji. Do sebe-projektování jedinec zahrnuje také souhrn rozličných identit, které se vytvářejí v mnoha vztazích. Smrtí se ztratí i tato mnohotvárná dimenze jedince. Současně také pozůstalí, mezi něž řadíme všechny vztahy, v nichž byla osobní identita zemřelého jedince zakotvena, se mohou cítit postiženi skrze tuto smrt i částečnou ztrátou vlastního já. Smrtí nehrozí zánik nějaké skupiny, ale do jisté míry narušení integrity osobních identit každé zúčastněné osoby.

V neo-moderním modelu smrti se viditelně objevují tendence, které se snaží osobní identitu každého jedince podporovat až do konce. ${ }^{17}$ Je to vyjádřeno zejména respektováním vlastního „já“, jakožto autority. Vlastní „já“ (self) vstupuje do procesu umírání jako aktivní subjekt, který tak může pokračovat v sebe-projektování. Jinými slovy podílet

17 V praxi neo-moderní model smrti umožňuje jednak výsledky hospicového hnutí, které se začaly objevovat od konce 60. let hlavně v anglosaských zemích, jednak konstituce paliativní medicíny (viz níže) jako součásti systému zdravotnictví. 
se v rámci možnosti na vytváření své osobní identity, nebở mu v podmínkách neo-moderního modelu zůstává jistá míra kontroly nad vlastní biografií.

Koncepce „udělat po svém“ přítomnost kontroly implikuje. V případě umírajícího je ovšem problematická míra sebe-kontroly. Vážně nemocné tělo často nepodléhá vlastní vůli jedince. Kontrola je proto zákonitě doprovázena jistou nutnou mírou závislosti. Dochází proto k jistému oddělení těla a vlastního „já“ (self), které je v pozdní modernitě v rámci sebe-projektování s tělem naopak ztotožňováno. ${ }^{18}$ Sebe-určení (self-determinatio) se už v této fázi nemůže plně vyjadřovat prostřednictvím těla, proto se projevuje skrze míru autenticity jedince v procesech rozhodovaní o způsobu léčby, samozřejmě po konzultacích s lékařem, který zastupuje „expertní systém“ [Giddens 1991], o tom, kde a jak si přeje zemř́t atd.

\section{Dobrá smrt}

Česká republika je př́kladem země, ve které stále ještě převažuje moderní typ smrti. ${ }^{19}$ Příčiny lze spatřovat v mnoha faktorech, mezi nimiž důležitou roli sehrává systém zdravotní péče a kulturní nebo společenské zvyklosti. Zároveň je na vině i zpožděný vývoj debat o potřebě zvláštní péče o umírající, což je společné pro všechny postsocialistické země [Clark - Wright: 2003]. Veřejná debata nad tématem smrti a umírání se tak možná také právě proto, že kvalitní paliativní a hospicová péče není všeobecně rozšířená, redukuje na legalizaci eutanazie, jako jediného řešení, které by do umírání mělo vnést důstojnost.

Problematika „důstojné smrti“ přináší zvláště v etické rovině více otázek než odpovědí. Západní společnost není v názorech na formu důstojné smrti jednomyslná, ale dělí se do dvou velkých skupin. Jednak jde o zastánce eutanazie, jednak jde o ty, co se od eutanázie distancují a požadují koncept tzv. dobré smrti v rámci paliativní medicíny. ${ }^{20}$ Sociologicky se zdá být velmi podnětný etymologický rozbor pojmu eutanazie (euthanasie), jak zdůrazňuje Kellehear [1990]. Upozorňuje, že pojem „dobrá smrt“ nemá etymologicky původ ve slově „Eu Thanatos“, jak se dnes automaticky chápe, nýbrž v řeckém „Kalos Thanatos“. Zatímco totiž význam termínu „Eu Thanatos“ odkazuje jen k bezbolestné, lehké smrti, výrazu „Kalos Thanatos“ se připisují pestřejší a sociálně proměnlivé charakteristiky. Jedná se o krásnou, ideální a příkladnou smrt. Př́́kladnou ve smyslu sociálně a kulturně připisovaných obsahů, nebot' „dobrá smrt ve smyslu 'Kalos Thanatos je současně také souborem kulturně uznávaného a předepsaného chováni“, které se podílí na „konstruování“ smysluplnosti smrti. [Kellehear in Clark, Seymour 2002: 88-89].

Ariès [2000] charakterizoval smrt v tradiční společnosti jako „zkrocenou“. Tato forma zároveň představuje kulturně a sociálně př́kladnou „dobrou smrt“ tohoto období. Zkrocenost odkazuje k faktu jisté míry kontroly jedince nad svou smrtí ve smyslu možné přípravy, kterou na jedné straně mohou zahrnovat řešení praktických záležitosti jako je závět', na druhé straně tato příprava může spočívat i v možnosti být při umírání doprovázen knězem. Protože se v tradiční společnosti umíralo často náhle a rychle, ne vždy byly tyto

18 Viz problém fragmentizace ,já“.

19 V nemocnících nebo jiných institucích jako jsou léčebny pro dlouhodobě nemocné nebo domovy důchodců umírá 80-92\% Čechů [Bártlová 2005: 64]. A pouze cca $1 \%$ zemřelých se dostává specializované paliativní péče [Sláma - Špinka 2004: 14].

20 Paliativní medicína - celostní péče (viz níže) o nevyléčitelně nemocného. Odstraňování fyzických, psychických a sociálních obtíží provázejícíc proces umírání. 
podmínky splněny. A tak ne vždy mohla být naplněna představa dobré smrti ve smyslu „Kalos Thanatos“, nicméně byla tato idea všeobecně rozšířená a známá.

V moderní západní společnosti se naproti tomu význam „dobré smrti“ ve smyslu „Kalos Thanatos“ postupně vytratil. Silnou měrou k tomu přispěla obecná sekularizace. Nicméně příčin lze vysledovat více, protože interpretační rámec náboženství není jediný, který konstruuje smysluplnost smrti. V jádru „dobré smrti“ (ve významu „Kalos Thanatos“) se nachází nějaké společné, vše prostupující téma, které se může proměňovat kulturně i sociálně. Dnes se smysl „dobré smrti“ zúžil na požadavek bezbolestné, pokud možno rychlé a nevědomé smrti. Absence širšího smyslu je předmětem všeobecné kritiky. Podle Bradburyho [1999] nastal posun v pojetí „dobré smrtí“ během 18. a 19. století, kdy s rozvojem moderní medicíny slábne strach o duši a je nahrazen otázkami týkající se samotné události fyzické smrti [Bradbury in Howarth 2007: 135].

Konkrétní forma socio-kulturního ideálu „dobré smrti“ dnes do značné míry chybí. Častěji se zmiňuje její negace, kterou zosobňuje smrt v nemocnici (hospitalized death). Mnohé o představě „dobré smrti“ lze proto implicitně vyčíst z charakteristiky této „institucionalizované smrti“. Smrt v nemocnici vystihuje „ztráta individuální volby, strach, izolace od rodiny, prátel i odborných pečovatelu, nedostatek vědomí o umírání a prodlužování dráhy umírání. “ [Clark - Seymour 2002: 89]. Nabízí se tedy otázka, nakolik je možné se v dnešních podmínkách vyhnout situacím, které proces umírání ztěžují, a vrátit se k ideji „dobré smrti“.

Východisko nabízí paliativní péče jako aktivní celostní péče o nemocného, když selhávají prostředky kurativní medicíny a nemoc již na léčbu nereaguje. V případě pokračování v léčbě, hrozí neúměrné prodlužování života na úkor jeho kvality, s čímž se současně vytrácí „přirozené umírání“ ve prospěch umělého umírání s př́stroji. Tvrzením, že není urychlováním smrti, se paliativní medicína zároveň distancuje od jakékoli formy eutanázie. Odstraňováním bolesti a úzkostných stavů se zaměřuje na rozměr kvality života umírajícího. Pokouší se pečovat o pacienta celostně, jako o člověka, nikoli jako o diagnózu nebo nemocný orgán, a uspokojovat také jeho psychosociální a spirituální potřeby. Zároveň do své péče začleňuje rodinu, a to jednak jako prvek v rámci multidisciplinárního týmů pečujících, jednak jako subjekt, na něhož je péče zaměřena $\mathrm{v}$ obtížném období umírání blízkého, ale také v pomoci při vyrovnávání se se ztrátou.

O uplatňování paliativní péče o umírající se velkou měrou zasloužilo hospicové hnutí v čele se svou zakladatelkou Cicely Saundersovou. Saundersová stála u zrodu myšlenky, že umírající mají kromě fyzických potřeb ještě potřeby psychologické, sociální a v neposlední řadě také spirituální. Sama prošla profesí sociální pracovnice, zdravotní sestry a lékařky, takže když svou ideu multidisciplinárních týmů prosadila do praxe, byla si vědoma většiny úskalí, kterým mohou členové těchto týmů čelit. Saundersová se zviditelnila zejména realizací prvního moderního hospice na světe v roce 1967 v Londýně. Před relativně krátkou dobou čtyřiceti let, které od otevření hospice St. Christopher uplynuly, byly pojmy jako hospicové hnutí nebo neo-moderní smrt ještě zcela neznámé. Nicméně projekt, který Saundersová prosazovala se založením speciální instituce pro zvláštní potřeby umírajících, ony pojmy zcela naplňoval a se zřízením prvního hospice také praktikoval.

Pod pojmem hospice proto nelze chápat jen místo ve smyslu budovy, ale také filosofii péče směřující k dosažení „dobré smrti“. Tuto filosofii kromě praktikování palia- 
tivní péče charakterizuje speciální organizace práce, kterou lze shrnout do několika následujících bodů: holistická péče, interdisciplinární týmy postrádající hierarchii, bez pevně vázaných rolí [Howarth 2007]. Je zde patrný pokus vymezit se od organizace nemocnice. Howarthová přičítá tyto tendence, které se objevují od 70. let zejména v USA, trendům deinstitucionalizace a demedicinalizace. $\mathrm{V}$ praxi tyto změny znamenaly snahu poskytnout nemocným nebo umírajícím, ale také lidem s mentálním nebo fyzickým postižením, přestárlým a dalším vlídné prostředí, které se ve způsobu organizace co možná nejvíce podobá rodinnému nebo komunitnímu společenství, není-li možné zabezpečit adekvátní péči přímo v domácím prostředí nemocného nebo umírajícího. Původní idea hospicového hnutí spočívala právě v založení formy jakési rozšířené rodiny, která by se mohla postarat o potřeby jak umírajícího, tak jeho rodiny [DuBois 1980 in Howarth 2007: 140].

Tento proces je dodnes postupný a neprobíhá ani v západní společnosti zcela rovnoměrně. Přesto určité tendence ${ }^{21}$ nasvědčují tomu, že obrat zájmu o situaci umírajících se bude dále prohlubovat, což se nutně odrazí v institucionálních změnách, v myšlení jedinců i v postoji celé společnosti.

\section{Závěr}

Vývoj tematizování problematiky umírání a smrti v sociologii, jak jsme si ho naznačili, od otázek sociálního řádu, náboženství přes sociologii medicíny k sociologii těla a umírání tvoří v obecnější rovině určitou paralelu k Walterové typologii tradiční, moderní a neo-moderní smrti. Jasně se to ukazuje zejména v př́padě převládajících autorit v jednotlivých typech (Bůh - tradice, nařízení lékaře a individuální přání -,já“). Tato triáda, která se $\mathrm{v}$ různých paralelách opakuje, odráží hlavní sociokulturní tendence v pojetí smrti a v neposlední řadě dokazuje, že smrt není jen neměnná biologická danost. Má tedy smysl reflektovat ji jako sociologický problém.

Podle Waltera dnes žijeme v éře revivalismu, tzn. návratu smrti a umírání do veřejného prostoru. $\mathrm{V}$ odborné rovině může být potvrzením tohoto trendu např́íklad vznik paliativní medicíny jako samostatného lékařského oboru, který se již nepokouší léčit a vyléčit, ale soustředí se na zvyšování kvality dožití umírajících. Lékař - paliativec už nechápe smrt jako prohru, což je v medicíně bezesporu něco nového. Vedle toho také zřizování hospiců, konstituování sociologie umírání a smrti nebo nárůst odborné péče dokazují jistý posun v postojích celé společnosti. Howarthová si všímá souvislostí tohoto posunu také mimo odbornou sféru a tvrdí, že v zábavním průmyslu se množí fil-my a seriály, ${ }^{22}$ které svou tématikou revivalismus odrážejí. Smrt totiž zobrazují bez

21 „V posledním desetiletí bylo opakovaně mnohými významnými celosvětovými, evropskými i národními institucemi zdůrazněno, že paliativni péče musí být jednou z prioritních oblastí rozvoje zdravotnické péče a že občané mají právo na její všeobecnou dostupnost. "[Sláma, Špinka 2004: 11]. Napřr. studie Priority Areas for National Action z roku 2003 (Institute of Medicine of the National Academies v USA) zařazuje rozvoj paliativní medicíny mezi šest nejdůležitějších úkolů zdravotní péče začátku 21. století [Sláma - Špinka 2004: 12].

22 Postavy těchto př́běhů často komentují děj jaksi s nadhledem „ze záhrobí“ (např. „Americká krása“, USA, 1999), „Zoufalé manželky“ (USA, 2004) nebo se s vědomím nevyléčitelné diagnózy snaží zrealizovat svá nesplněná přání („Klepání na nebeskou bránu“, SRN, 1997), „Než si pro nás př́ijde“ (USA, 2008). Jiným z řady př́kladů, kterým celý výčet nekončí, může být také seriál z prostředí rodinnné pohřební služby „Odpočívej v pokoji“ (USA, 2001). 
krve a násilí, jak je zvykem v detektivních nebo válečných př́bězích či thrillerech, nýbrž tak, jak se často „děje i nám“ jako vyústění dlouhé nemoci [Howarth 2007]. Lze se s nimi tedy více identifikovat.

Také seriály z lékařského prostředí, které byly vždy populární, se proměňují. Zatímco dříve spíše oslavovaly všemocnost moderní medicíny, v posledních letech se do popředí dostávají více pocity nemocných a umírajících nebo vztahy zdravotnického personálu k pacientovi a jeho rodině. Trend obliby seriálů a filmů, které současně otevřeně a poměrně citlivě pracují se smrtí jako s přirozenou součástí života, nasvědčují tomu, že jedinci začínají přemýšlet o problematice, která je v západní společnosti stále viditelnější. Potvrzuje se tak tedy i v této podobě, že smrt přestala být tabu. A současně tento trend může ukazovat, že ve společnosti roste „existenciální“ potřeba „dobré smrti“ ve smyslu Kalos Thanatos. 


\section{Literatura}

Ariès, Phillipe. [2000]. Dějiny smrti I.. Praha: Argo.

Ariès, Phillipe. [2000]. Dějiny smrti II., Praha: Argo.

Badham, Paul - Ballard Paul. et al. [1996]. Facing Death: An Interdisciplinary Aprroach. Cardiff: University of Wales Press.

Balsamo, Anne. [1997]. Technologies of the Gendered Body: Reading Cyborh Woman. London: Duke University Press.

Bártlová, Sylva. [2005]. Sociologie medicíny a zdravotnictví. Praha: GRADA Publishing.

Bauman, Zygmunt. [1995]. Úvahy o postmoderní době. Praha: SLON.

Bláha, Inocenc A. [1997]. Československá sociologie. Brno: Doplněk.

Clark, David. et al. [1993]. The Sociology of Death: theory, culture, practise. Oxford: Blackwell Publishers.

Clark, David - Seymour, Jane E. [2002]. Reflections on Palliative Care. Buckingham -Philadelphia: Open University Press.

Clark, David - Wright, Michael. [2003]. Transitions in End of Life Care: Hospice and Related Developments in Eastern Europe and Central Asia. Buckingham: Open Univesity Press.

Davies, Douglas J. [2007]. Stručné dějiny smrti. Praha: Volvox Globator.

Elias, Norbert. [1998]. O osamělosti umírajících v našich dnech. Praha: Nakladatelství Franze Kafky.

Featherstone, Mike. [1991]. The Body in Consumer Culture. In. Featherstone, Mike - Hepworth, Mike - Turner, Bryan S. (eds.). The Body: Social Process and Cultural Theory. London: Sage, s. $170-196$.

Featherstone, Mike - Hepworth, Mike. [1991]. The Mask of Ageing and the Postmodern Life Course. In. Featherstone, Mike - Hepworth, Mike - Turner, Bryan S. (eds.). The Body: Social Process and Cultural Theory. London: Sage, s. 371-389.

Giddens, Anthony. [2001]. Modernity and Self-Identity. Cambridge: Polity.

Giddens, Anthony. [2003]. Di̊sledky modernity. Praha: SLON.

Glaser, Barney - Strauss, Anselm. [1965]. Awareness of Dying. Chicago: Aldine.

Goffman, Erving. [2003]. Stigma. Praha: SLON.

Gorer, Geoffrey. [1965]. Death, Grief and Mourning in Contemporary Britain. London: Cresset.

Haškovcová, Helena. [2002]. Lékařská etika. Praha: Galén.

Howarth, Glennys. [2007]. Death and Dying. A Sociological Introduction. Cambridge: Polity.

Howson, Alexandra. [2005]. The Body in Society. An Introduction. Cambridge: Polity.

Illich, Ivan. [2002]. Limits to Medicine. Medical Nemesis. The Expropriation of Health. London - New York: Marion Boyars.

Kastenbaum, Robert J. [2004]. Death, Society, and Human Experience. Boston: Pearson Education.

Kellehear, Alan. [1990]. Dying of Cancer. The Final Year of Life. London: Harwood Academic.

Kř́žová, Eva. [2006]. Proměny lékařské profese z pohledu sociologie. Praha: SLON.

Kübler-Ross, Elisabeth. [1993]. O smrti a umírání. Trutnov: Arica.

Lawson, Julie. [1998]. Contemporary Hospice Care: the Sequestration of the Unbounded Body and 'Dirty Dying: Sociology of Health and Illness 20 (1998), No. 2, s. 121-143.

Littlewood, Jane. [1993]. The Denial of Rites of Passage in Contemporary Societies. In. Clark, D. [ed.]. The Sociology of Death: Theory, Culture, Practice. Oxford: Blackwell Publishers, s. 69-84.

Malinowski, Bronislaw. [1962]. The Role of Magic and Religion. In. Lessa, William A. - Vogt, Evon Z. (ed.). Reader in Comparative Religion. New York: Harper and Row, s. 102-112.

Mellor, Philip A. [1993]. Death in High Modernity. In. Clark, David. [ed.]. The Sociology of Death: theory, culture, practise. Oxford: Blackwell Publishers, s. 11-30.

Možný, Ivo. [1990]. Moderní rodina (mýty a skutečnost). Brno: Nakladatelství Blok.

Petrusek, Miloslav. [2006]. Společnosti pozdní doby. Praha: SLON. 
Přidalová, Marie. [1998]. Proč je moderní smrt tabu? Sociologický časopis 34 (1998), č. 3, s. $347-361$.

Shilling, Chris. [2004]. The Body and Social Theory. London: Sage Publications.

Sláma, Ondřej - Špinka, Štěpán. [2004]. Koncepce paliativní péče v ČR. Praha: Cesta domů.

Sudnow, David. [1967]. Passing On The Social Organisation of Dying. New York: Prentice Hall. Šubrt, Jiř́. [2001]. Postavy a problémy soudobé teoretické sociologie. Praha: ISV nakladatelství.

Šubrt, Jiří. et al. [2006]. Talcott Parsons a jeho př́nos soudobé sociologické teorii. Praha: Karolinum.

Turner, Bryan S. [2004]. The Body and Society. London: SAGE Publications.

Turner, Bryan S. [2006]. The Cambridge Dictionary of Sociology. New York: Cambridge University Press.

Vorlíček, Jiří. et al. [2004]. Paliativní medicína. Praha: GRADA Publishing.

Walter, Tony. [2005]. The Revival Of Death. London - New York: Routledge.

Walter, Tony. [1993]. Sociologist Never Die: British Sociology and Death. In. Clark, David. [ed.]. The Sociology of Death: Theory, Culture, Practice. Oxford: Blackwell Publishers, s. 264-295.

Lenka Beranová (1981) vystudovala sociologii na Filozofické fakultě Univerzity Karlovy v Praze. Od ledna 2008 pracuje ve výzkumné agentuře STEM/MARK, kde se nyní věnuje zejména oblasti internetových výzkumů. Současně jako dobrovolník spolupracuje s občanským sdružením provozujícím domácí hospic Cesta domů. Zajímá se o problematiku lidského těla $v$ sociálních vědách, sociologii umírání a smrti a sociologii medicíny. Opakovaně publikovala v českých denících (MF Dnes, Lidové noviny) a dále ve sborníku Medicína v kontextu západního myšlení (2008). 